Available online at: http://ejournal-balitbang.kkp.go.id/index.php/iaj

\title{
DETERMINING THE OPTIMUM TEMPERATURE FOR GROWTH, FEED EFFICIENCY AND SURVIVAL OF DOMESTICATED INDONESIAN MAHSEER, TOr SORO LARVAE
}

\author{
Jojo Subagja"), Emir Ma'arif Imamudin**), Kurniawan Kurniawan*\#, Agoes Soeprijanto*), and \\ Yunita Maimunah*) \\ *) Research Institute for Freshwater Aquaculture and Fisheries Extension \\ Jl. Sempur No. 1, Bogor 16129 \\ *4) Faculty of Fisheries and Marine Science, Brawijaya University, Malang
}

(Received: July 6, 2021; Final revision: September 13, 2021; Accepted: September 13, 2021)

\begin{abstract}
Temperature plays a pivotal role in the success of larvae production. Evaluation of the effects of different temperatures on growth, feed efficiency, and survival of domesticated Indonesian mahseer (Tor soro) larvae was carried out to determine an optimum rearing temperature. Five different temperature settings of $22^{\circ} \mathrm{C}$, $24^{\circ} \mathrm{C}, 26^{\circ} \mathrm{C}, 28^{\circ} \mathrm{C}$, and $30^{\circ} \mathrm{C}$ were used as the treatments arranged in triplicates, in indoor closed recirculating systems. The larvae were stocked in a rectangular glass tank with a stocking density of 150 larvae per tank and fed with a commercial feed (30\%protein content) three times a day, about $10 \%$ per body weight over 61 days of observation. Measured parameters included the specific growth rate of total weight $\left(\mathrm{SGR}_{\mathrm{TW}}\right)$ and length $\left(S G R_{T L}\right)$, feed efficiency $(F E)$, and survival rate $(S R)$. The result showed that the treatments of different temperatures significantly affected the growth performance and feed efficiency of the larvae. The growth performance and feed efficiency of mahseer larva were much better at rearing temperature from $24^{\circ} \mathrm{C}$ to $28^{\circ} \mathrm{C}$ compared with those at $22^{\circ} \mathrm{C}$ and $30^{\circ} \mathrm{C}$. There were no significant differences in SR in different temperatures tested. The SR was found to range from $86.44 \%$ to $100 \%$ in all treatments. Maintaining temperature ranging from $24^{\circ} \mathrm{C}$ to $28^{\circ} \mathrm{C}$ is the best rearing condition to achieve the optimum growth and feed efficiency of mahseer during the larval rearing period. The findings from this research could be set as a standard technique in larval rearing of Indonesian mahseer (Tor soro).
\end{abstract}

KEYWORDS: rearing temperature; mahseer hatchery; Kancra; Dewa; RAS

\section{INTRODUCTION}

Mahseer is a highly valued and culturally important cyprinid fish in Southeast Asia (Pinder et al., 2019). In Indonesia, Mahseer Tor soro, locally known as "Ikan Kancra" or "Ikan Dewa", can be found in the freshwater ecosystem in Sumatera, Kalimantan, and Java Islands (Kottelat et al., 1993). This species is used as an iconic offering in multiple cultural ceremonies in these regions. However, the supply of fish production mainly depends on inland fisheries, especially in riverine areas (Haryono \& Subagja, 2007). Exploitation and habitat degradation of this iconic fish have increased in the last decade, decreasing the fish populations in many regions (Wahyuningsih et al., 2012). In dealing with this issue, the Research Institute for Freshwater Aquaculture and Fisheries Extension (RIFAFE),

\footnotetext{
\# Correspondence: Research Institute for Freshwater Aquaculture and Fisheries Extension.

Jl. Sempur No. 1, Bogor 16129

E-mail: kurniawan79@ kkp.go.id
}

Bogor, Indonesia, has successfully domesticated the fish since 2011 and initiated to promote its hatchery technology for seed production for aquaculture and conservation (Gustiano et al., 2013; Kurniawan et al., 2021).

Various studies have been conducted to support the improvement of hatchery technology for Tor soro aquaculture, including evaluating its broodstock management (Subagja et al., 2006), hormonal treatment on eggs maturation and spawning larvae (Gustiano \& Subagja, 2006; Farastuti et al., 2014), stocking density in larval rearing (Qudus et al., 2012), and incubation temperatures effects on eggs and embryonic development (Arifin et al., 2020). However, the effects of rearing temperature on larval development and survival performances of Tor soro have not yet been investigated. Temperature significantly affects the growth, survival, and physiological performance of fish species (Boltana et al., 2017; Prakoso \& Kurniawan, 2020; Takata et al., 2014). Temperature ranges have different effects different responses on 
the optimum growth rate, biomass, and survival of different fish species (da Costa et al., 2016; Rønnestad et al., 2013; Pyanuth et al., 2020). Therefore, it is essential to understand thermal influences on cultured fish to improve larval rearing in aquaculture (Prakoso et al., 2019; Singh et al., 2013; Tang et al., 2017).

The range of temperature implemented for optimum larval rearing of mahseer was found different among various mahseer species. The effects of different rearing temperatures on Semah Mahseer Tor douronensis larvae showed that the highest growth of larvae was observed at temperature $26^{\circ} \mathrm{C}$. In contrast, the highest survival rate of larvae was identified at $24^{\circ} \mathrm{C}$ (Arifin et al., 2021). On the other hand, the Malaysian mahseer Tor tambroides need a higher temperature for their optimum growth of about $30^{\circ} \mathrm{C}$ (Das et al., 2018). The rearing temperature for the mass production larvae of golden mahseer Tor putitora ranges from $20^{\circ} \mathrm{C}$ to $27^{\circ} \mathrm{C}$ (Sarma et al., 2010). The preferred temperature for larval rearing of chocolate mahseer Neolissochilus hexagonolepis ranges from $23^{\circ} \mathrm{C}$ to $27^{\circ} \mathrm{C}$, and the optimum temperature for growth was predicted about $25^{\circ} \mathrm{C}$ (Dash et al., 2021).

This research aimed to evaluate the effects of different temperatures on growth, feed efficiency, and survival performances of domesticated Indonesian mahseer (Tor soro) larvae reared in a recirculating aquaculture system.

\section{MATERIALS AND METHODS}

\section{Fish Larvae}

This research was conducted at the Research Institute for Freshwater Aquaculture and Fisheries Extension (RIFAFE), Cijeruk, Bogor, Indonesia, from May to July 2019. Fish larvae were used in this experiment aged 31 days after hatching produced by the artificial reproduction method. The initial length and weight of the larvae were $1.48 \pm 0.05 \mathrm{~cm}$ and 0.02 $\pm 0.00 \mathrm{~g}$, respectively. The first generations of sexually mature Tor soro broodstocks were selected for artificial reproduction. Commercial hormone Ovaprim $^{T M}(0.6 \mathrm{~mL} / \mathrm{kg}$ body weight) was injected intramuscularly to accelerate gonad maturation. Ovulation of eggs mainly occurred after a 12-hour injection. The eggs dan sperms were released by stripping method and mixed in containers filled with $\mathrm{NaCl}$ solution. Freshwater was added to the mixture to allow fertilization. Egg incubation was carried out in rectangular tanks and larvae were commonly hatched after 24 hours. Five days after hatching, the larvae were fed ad libitum with Artemia sp. nauplii for up to 14 days. Subsequently, a commercial diet (30\% protein content) was given to the larvae at satiation two times a day until a month-rearing period. Then, the larvae (31 days after hatching) were removed from incubation tanks to rectangular tanks for 61 days experiment.

\section{Experimental Design}

This study used a completely randomized design using five temperature treatments where each treatment had three replications. Five different temperature settings of $22^{\circ} \mathrm{C}, 24^{\circ} \mathrm{C}, 26^{\circ} \mathrm{C}, 28^{\circ} \mathrm{C}$, and $30^{\circ} \mathrm{C}$ were used as the treatments arranged in triplicates $30-\mathrm{L}$ tanks. These temperature ranges were based on the preliminary study and current practices of mahseer larval rearing in different hatcheries. The fish tanks used in this experiment were glass aquaria sized 40 $\mathrm{cm} \times 30 \mathrm{~cm} \times 30 \mathrm{~cm}$ (LXWXH) aerated by a bubbling system. Each fish tank was connected to a recirculating aquaculture system and set to each specified temperature level using an automatic thermostat (ResunCL450). The stocking density used was 150 fish per tank. Fish larvae were fed with a commercial feed three times a day, about $10 \%$ per body weight, during 61 days of observation. Sampling was carried out at the beginning and the end of the study. The lengths of the larvae were measured using laminated paper block (accuracy $0.1 \mathrm{~mm}$ ) and weight was measured using a digital balance (accuracy $0.01 \mathrm{~g}$ ).

\section{Water Quality Monitoring}

The temperature levels were kept constant and regularly monitored during the 61 days experiment. Water quality measurements were carried out every two weeks following data sampling. The water quality parameters measured were $\mathrm{pH}$ ( $\mathrm{pH}$-meter digital, Hanna HI98107) and dissolved oxygen (DO meter, Trans Instrument HD3030). In the present study, pH and DO were still within the acceptable range for fish growth (Table 1).

\section{Data Analysis}

Growth, feed efficiency, and survival performances of Tor soro larvae reared using different temperature settings were calculated using the following equations.

Specific growth rate (SGR):

$$
\mathrm{SGR}(\mathrm{TW})=\frac{\ln W \mathrm{t}-\ln \mathrm{Wi}}{\mathrm{t}} \times 100
$$

Where: $W t=$ final weight

Wi $=$ initial weight

$$
\operatorname{SGR}(T L)=\frac{\ln L t-\ln L i}{t} \times 100
$$


Table 1. Water quality conditions measured in fish tanks with different temperature settings during the experiment

\begin{tabular}{lcc}
\hline \multicolumn{1}{c}{ Parameters } & Values & References \\
\hline pH & $6.90(6.88-6.92)$ & $6.5-8.0($ Arifin et al ., 2019) \\
DO $(\mathrm{mg} / \mathrm{L})$ & $5.21(4.54-5.65)$ & $>2($ Pratama et al ., 2018) \\
\hline
\end{tabular}

Where: $L t=$ final length

$L i=$ initial length

$\mathrm{t}=$ the cultured period in a day

In $=$ logarithmic natural

Feed efficiency (FE):

$$
\mathrm{FE}=\frac{1}{\mathrm{PCR}} \times 100
$$

Feed conversion ratio (FCR)

$$
\mathrm{FCR}=\frac{\text { Total feed intake }(\mathrm{g})}{\text { Total weight gain }(\mathrm{g})}
$$

Survival rate (SR):

$$
\mathrm{SR}(\%)=\frac{\mathrm{Nf}}{\mathrm{Ni}} \times 100
$$

Where: $\mathrm{Nf}=$ final number of live fish

$$
\mathrm{Ni}=\text { the initial number of larvae }
$$

The effects of temperature on larval growth and survival were statistically evaluated using analysis of variance (ANOVA) to determine significant differences of the experiment, followed by Duncan's Multiple Range Test (DMRT) to identify the best responses among treatments. The significance level was set to $\alpha=0.05$. All statistical analyses were performed using SPSS 16.

\section{RESULTS AND DISCUSSION}

Growth performance and feed efficiency of Tor soro larvae reared using five temperature settings are shown in Table 2. There was a significant difference in the specific growth rate of total weight $\left(\mathrm{SGR}_{\mathrm{TW}}\right)$ and total length $\left(\mathrm{SGR}_{\mathrm{TL}}\right)$ among different temperatures $(P<0.05)$. The results of the DMRT post hoc test revealed that the treatment temperatures of $24^{\circ} \mathrm{C}, 26^{\circ} \mathrm{C}$, and $28^{\circ} \mathrm{C}$ were not significantly different in both $\mathrm{SGR}_{\text {,w }}$ and $\mathrm{SGR}_{\mathrm{T}}$, while the treatment temperatures of $22^{\circ} \mathrm{C}$ and $30^{\circ} \mathrm{C}$ were significantly different in both $S_{G} R_{T W}$ and $\mathrm{SGR}_{\mathrm{TL}}$ as compared with treatment temperatures of $24^{\circ} \mathrm{C}, 26^{\circ} \mathrm{C}$, and $28^{\circ} \mathrm{C}$. These conditions were also supported by the feed efficiency of the fish that was significantly impacted by different temperatures $(P<0.05)$. The treatment temperatures of $24^{\circ} \mathrm{C}, 26^{\circ} \mathrm{C}$, and $28^{\circ} \mathrm{C}$ were not significantly different in feed efficiency, while the temperature settings of $22^{\circ} \mathrm{C}$ and $30^{\circ} \mathrm{C}$ were significant differences in feed efficiency as compared with $24^{\circ} \mathrm{C}, 26^{\circ} \mathrm{C}$, and $28^{\circ} \mathrm{C}$. These findings indicated that temperature settings ranging from $24^{\circ} \mathrm{C}$ to $28^{\circ} \mathrm{C}$ are the optimum temperature for Tor soro growth, while temperatures of $22^{\circ} \mathrm{C}$ and $30^{\circ} \mathrm{C}$ are not recommended for Tor soro larvae rearing.

The trend of specific growth rate in weight and length and feed efficiency increased from $22^{\circ} \mathrm{C}$ until they reached maximum points at temperature about $26.0^{\circ} \mathrm{C}$ and decreased with further temperature increase (Figure 1). This model is in line with the research conducted by Bar \& Radde (2009), who reported that the effects of different temperatures on the growth of fish commonly followed bell-shaped curves. This pattern is possibly related to the metabolic rate of most fish species which increases at an optimum temperature and decreases at higher and lower temperatures (Emaliana et al., 2016).

Table 2. Growth performance and feed efficiency of Tor soro larvae reared using five temperature settings $\left(22^{\circ} \mathrm{C}, 24^{\circ} \mathrm{C}, 26^{\circ} \mathrm{C}, 28^{\circ} \mathrm{C}\right.$, and $\left.30^{\circ} \mathrm{C}\right)$ during the 61 days experiment

\begin{tabular}{cccc}
\hline Temperature treatments $\left({ }^{\circ} \mathbf{C}\right)$ & SGR $_{\text {Tw }}(\%$ day) & SGR $_{\text {TL }}(\%$ day) & Feed efficiency (\%) \\
\hline 22 & $0.121 \pm 0.007^{\mathrm{a}}$ & $1.107 \pm 0.035^{\mathrm{a}}$ & $59.60 \pm 3.20^{\mathrm{a}}$ \\
24 & $0.159 \pm 0.008^{\mathrm{b}}$ & $1.341 \pm 0.033^{\mathrm{b}}$ & $77.16 \pm 6.40^{\mathrm{b}}$ \\
26 & $0.162 \pm 0.014^{\mathrm{b}}$ & $1.355 \pm 0.05^{\mathrm{b}}$ & $78.85 \pm 4.81^{\mathrm{b}}$ \\
28 & $0.151 \pm 0.006^{\mathrm{b}}$ & $1.300 \pm 0.033^{\mathrm{b}}$ & $73.07 \pm 1.90^{\mathrm{b}}$ \\
30 & $0.120 \pm 0.01^{\mathrm{a}}$ & $1.093 \pm 0.029^{\mathrm{a}}$ & $55.375 .10^{\mathrm{a}}$ \\
\hline
\end{tabular}

Note: Values are means $\pm S D(n=3)$. Superscript letters represent significant differences $(P<0.05)$ between different temperatures 

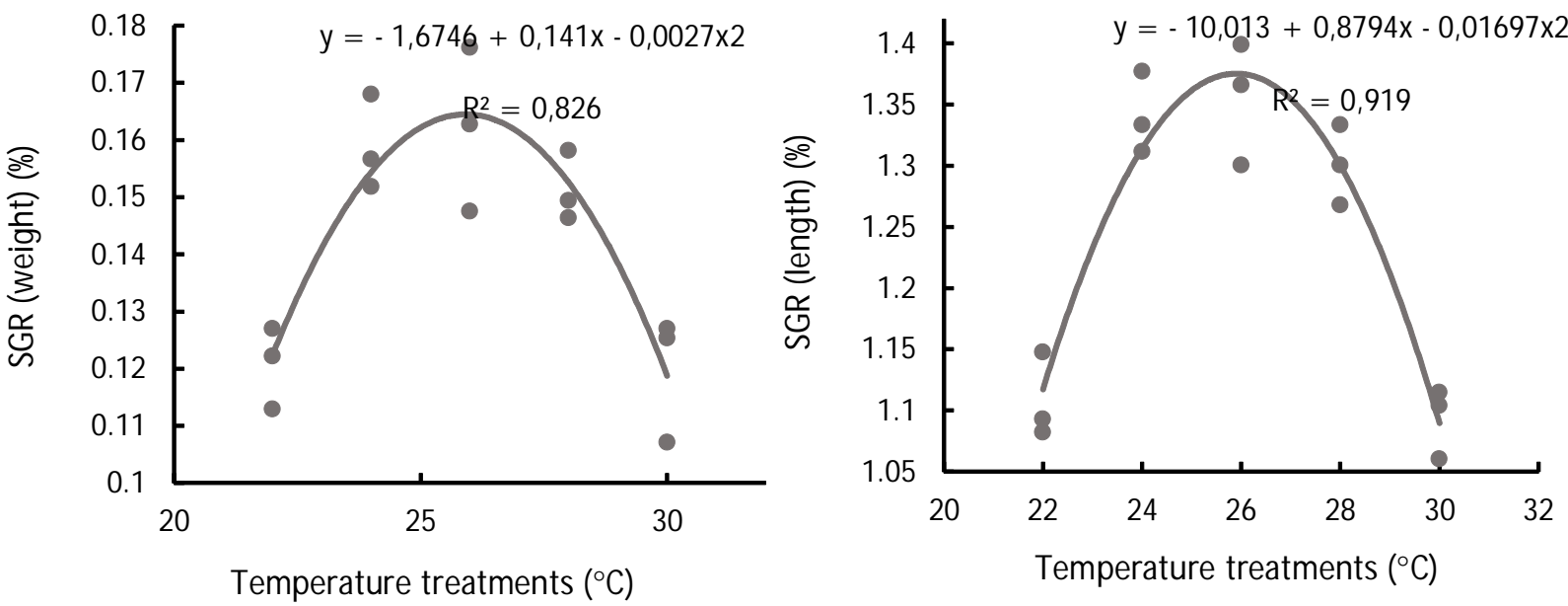

Figure 1. Polynomial regression models of the specific growth rate of weight and length of Tor soro larvae reared at different temperatures.

The excellent growth of fish is influenced by several water quality parameters. Temperature and feed are the most significant factors in successful larval rearing (Kolman et al., 2018; Karimah et al., 2018). Fish larvae are susceptible to changes in environmental conditions, especially temperature. Low temperatures reduce the activity of cells that inhibits fish growth. For instance, a change of $1^{\circ} \mathrm{C}$ will affect metabolic change reactions in the fish body by $10 \%$ (Pratama et al., 2018). The effects of temperature on fish can be observed in some metabolic processes, including growth, feed intake, and survival (Abram et al., 2017; Nytrø, 2013). The optimum temperature accelerates fish metabolism, which positively influences fish growth, while low temperatures decrease metabolic rate, fish appetite, feed intake, and eventually lead to slower fish growth (Islam et al., 2019). Also, the difference in altitude impacts water quality parameters that affect fish growth. In this case, temperature plays a pivotal role in fish's fast or slow growth traits (Subagja et al., 2018).

In this study, the growth of Mahseer Tor soro was higher than wild mahseer reared in the pond for the domestication program. The growth of three wild population mahseer Tor soro only reached SGR around $0.61 \%$ day (Asih \& Setijaningsih, 2011). However, the growth of mahseer was categorized as a slow-growth performance as compared with other cultured fish larvae such as Common carp Cyprinus carpio (SGR: $3.82 \%$ day at $28^{\circ} \mathrm{C}$ ) (Desai et al., 2009) and African catfish Clarias gariepinus $\left(5.14 \%\right.$ day at $28^{\circ} \mathrm{C}$ ) (Orina et al., 2016). The optimum temperature for the excellent growth of fish in the Cyprinidae family commonly ranged from $25^{\circ} \mathrm{C}$ to $27^{\circ} \mathrm{C}$ (Ariyana, 2015; Ridwantara et al., 2019). Fish need specific temperatures for their optimum growth rate, feeding efficiency, and nutrient utilization (Bogevik et al., 2010). Feed intake by fish was influenced by different temperatures, which affect enzyme activity (Kamarudin et al., 2011). The increase of enzyme activity relates to the increasing efforts of fish in digesting nutritional content, especially protein, for its optimal growth (Gheisvandi et al., 2014). Thus, it can be explained that the higher the feed efficiency value, the better fish response to feeding, leading to growth acceleration.

Effects of different temperatures on the survival rate (SR) of larvae were not significantly different $(P>0.05)$ (Figure 2). These results indicate that the temperature range from $22^{\circ} \mathrm{C}$ to $30^{\circ} \mathrm{C}$ in this experiment is still within the acceptable level for mahseer rearing. Still, it provides a different performance in their growth. Survival rate can be influenced by biotic and abiotic factors, abiotic factors including food availability and quality of cultured media (Istiqomah et al., 2018). Temperature is an environmental parameter that affects the survival and development of fish larvae and plays a major role in accelerating the metabolism of the fish (Rønnestad et al., 2013).

The effects of temperature on the survival rate (SR) of the other mahseer species are also present in different performance characteristics. Semah mahseer Tor douronensis larvae have a wide range of temperature regimes. This species can be reared at the temperature of $24^{\circ} \mathrm{C}$ to $32^{\circ} \mathrm{C}$, and the optimum temperature was $24^{\circ} \mathrm{C}$ indicated by the highest SR $(83.50 \%)$ (Arifin et al., 2021). Similarly, Malaysian mahseer T. tambroides also has excellent survival in wider temperature settings ranging from $22^{\circ} \mathrm{C}$ to $30^{\circ} \mathrm{C}$ (Das et al., 2018). However, compared to other Cyprinids, mahseer is likely more tolerance to wider range of rearing temperature. The effective rearing temperature of the Rohu carp Labeo rohita ranges from $24^{\circ} \mathrm{C}$ to $26^{\circ} \mathrm{C}$ (Kausar \& Salim, 2006). The common carp Cyprinus carpio fry can be optimally reared at $28^{\circ} \mathrm{C}$ to 


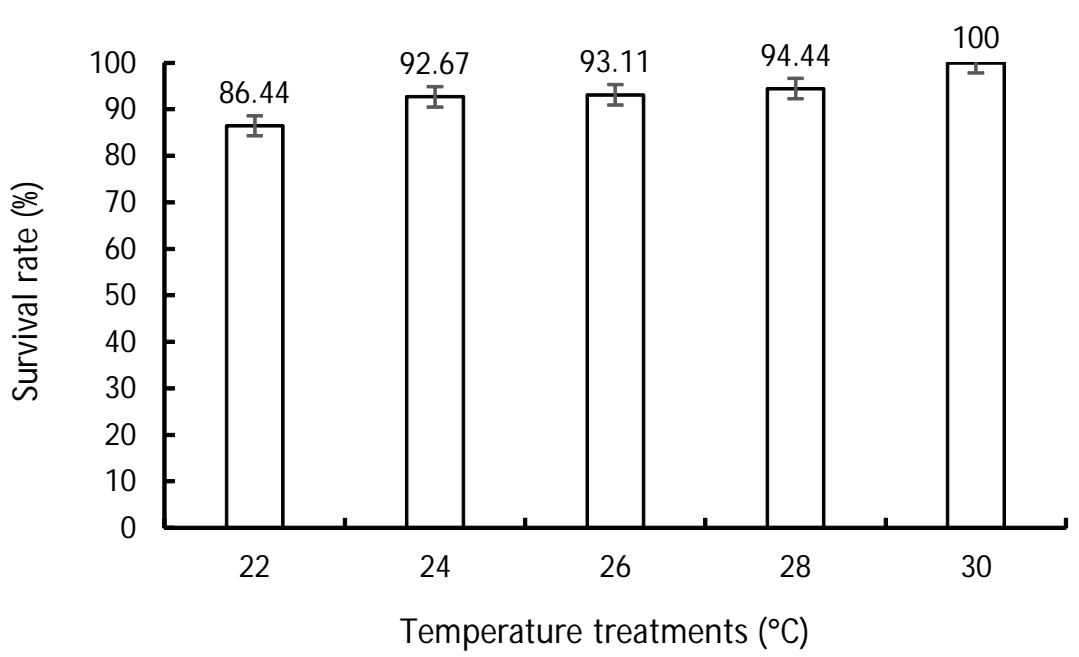

Figure 2. Survival rate of domesticated mahseer larvae reared in five temperature conditions.

$30^{\circ} \mathrm{C}$ (Laila, 2018). The temperature range for Goldfish (Carasius auratus) larval rearing was determined to be from $27^{\circ} \mathrm{C}$ to $30^{\circ} \mathrm{C}$, and the optimum temperature was observed at $29^{\circ} \mathrm{C}$ (Sihombing, 2018).

\section{CONCLUSION}

The ambient water temperatures ranging from $22.0^{\circ} \mathrm{C}$ to $30.0^{\circ} \mathrm{C}$ are still within the acceptable level for survival of mahseer Tor soro larvae. This study suggests that $24^{\circ} \mathrm{C}$ to $28^{\circ} \mathrm{C}$ is the optimum temperature range to achieve better growth and feed efficiency of mahseer Tor soro during the larval rearing period. The result of this study could be incorporated into the technical development standard of mahseer Tor soro larval rearing in hatcheries.

\section{ACKNOWLEDGMENTS}

The authors acknowledge Otong Zenal Arifin and Deni Irawan at the Research Institute for Freshwater Aquaculture and Fisheries Extension (RIFAFE), Bogor, for excellent supports and assistance during the experiment.

\section{REFERENCES}

Abram, Q.H., Dixon, B., \& Katzenback, B.A. (2017). Impacts of low temperature on the teleost immune system. Biology, 6(39), 1-15.

Arifin, O.Z., Mumpuni, F.S., Sofian, A., \& Hasan, O.D.S. (2020). Embrio development of Mahseer (Tor soro) at different temperature during egg incubation. Media Akuakultur, 15(2), 53-59.

Arifn, 0.Z., Mulyana, \& Saputri, S. (2021). Growth performance and survival rate of Semah mahseer Tor douronensis reared at different temperatures. Jurnal Mina Sains, 7(1), 1-8.
Ariyana. (2015). Growth and feed efficiency of the koi carp (Cyprinus carpio) fed with different type of the pasta feed. Thesis. Universitas Hasanuddin, Makassar.

Asih, S. \& Setijaningsih, L. (2011). The success of mahseer breeding (Tor soro) collected from the North Sumatera (Aek Sirambe, Tarutung dan Bahorok) for the native fish conservation. Proceeding of The National Forum for Fish Resources Improvement III. Research and Development Institute for Freshwater Aquaculture. Bogor. p. 1-7.

Bar, N.S. \& Radde, N. (2009). Long-term prediction of fish growth under varying ambient temperature using a multiscale dynamic model. BMC Systems Biology, 3(107), 1-19.

Boltana, S., Sanhueza, N., Aguilar, A., GallardoEscarate, C., Arriagada, G., Valdes, J.A., Soto, D., $\&$ Quinones, R.A. (2017). Influences of thermal environment on fish growth. Ecology and Evolution, 7, 6814-6825.

Bogevik, A.S., Henderson, R.J., Mundheim, H., Waagbø, R., Tocher, D.R., \& Olsen, R.E. (2010). The influence of temperature on the apparent lipid digestibility in Atlantic salmon (Salmo salar) fed Calanus finmarchicus oil at two dietary levels. Aquaculture, 309, 143-151.

da Costa, D.P., Leme, D.O.P., Takata, F., Costa, R., de Souza e Silva, D.C., Filho, W.M., Alves, R.G. M., \& Luz, R.K. (2016). Effects of temperature on growth, survival, and physiological parameters in juveniles of Lophiosilurus alexandri, a carnivo rous neotropical catfish. Aquaculture Research, 47, 1706-1715.

Das, S.K., Noor, N.M., Kai, K.S., Juan, Q.Z., Iskandar, M.N.S. \& De, M. (2018). Effects of temperature 
on the growth, gastric emptying time, and oxygen consumption rate of mahseer (Tor tambroides) under laboratory conditions. Aquaculture Reports, 12, 20-24.

Dash, P., Tandel, R.S., Pandey, N., Sawant, P.N., Sarma, D., Rawat, K.D., \& Chadha, N.K. (2021). Effects of rearing temperature on egg incubation, growth, standard metabolic rate, and thermal tolerance of chocolate mahseer, Neolissochilus hexagonolepis. Journal of Thermal Biology, 98, 102942.

Desai, A.S. \& Singh, R.K. (2009). The effects of water temperature and ration size on growth and body composition of fry of common carp, Cyprinus carpio. Journal of Thermal Biology, 34, 6, 276-280.

Emaliana, S., Usman, \& Lesmana, I. (2016). The effect of different temperatures on the growth of the koi carp larvae (Cyprinus carpio). Jurnal Aquacoastmarine, 13(3), 1-10.

Farastuti, E.R., Sudrajat, A.O., \& Gustiano, R. (2014). Ovulation and breeding inductions of mahseer (Tor soro) using different hormonal treatments. Limnotek, 21(1), 87-94.

Gheisvandi, N., Hajimoradloo, A., \& Hoseinifar, S.H. (2014). The effect of water temperature on food transit time and digestive enzyme activity in Caspian kutum (Rutilus kutum) larvae. International Journal of Aquatic Biology, 2, 138-146.

Gustiano, R., Kontara, E.K., Wahyuningsih, H., Subagja, J., Asih, S., \& Saputra, A. (2013). Domestication of mahseer (Tor soro) in Indonesia. Communications in Agricultural and Applied Biological Sciences, 78(4), 165-168.

Gustiano, R. \& Subagja, J. (2006). The effect of HCG hormone implantation on the eggs development, final maturation, and spawning rate of Tor soro. Jurnal Riset Akuakultur, 1(2), 219-225.

Haryono, H. \& Subagja, J. (2007). The growth of Tambra mahseer (Tor tambroides) dan Mahseer (Tor soro) fed with different diets during domestication. Jurnal Biologi Indonesia, 4(3), 167-175.

Islam, M.A., Uddin, M.H., Uddin, M.J., \& Shahjahan, M. (2019). Temperature changes influenced the growth performance and physiological functions of Thai pangas Pangasianodon hypophthalmus. Aquaculture Reports, 13, 100179.

Istiqomah, D.A., Suminto, \& Harwanto, D. (2018). The effects of different level of water quality exchanges on survival, feed efficiency and growth of monosex tilapia (Oreochromis niloticus) larvae. Jurnal of Aquaculture Management and Technology, $7(1), 46-54$.
Kamarudin, M.S., Otoi, S., \& Saad, C.R. (2011). Changes in growth, survival, and digestive enzyme activities of Asian redtail catfish, Mystus nemurus, larvae fed on different diets. African Journal of Biotechnology, 10(21), 4484-4493.

Karimah, U., Samidjan, I., \& Pinandoyo. (2018). The growth and survival performances of GIFT tilapia (Oreochromis niloticus) fed with different quantity of diets. Jurnal of Aquaculture M anagement and Technology, 7(1), 128-135.

Kausar, R. \& Salim, M. (2006). Effect of water temperature on the growth performance and feed conversion ratio of Labeo rohita. Pakistan Veterinary Journal, 26(3), 105-108.

Kolman, R., Khudyi, O., Kushniryk, O., Khuda, L., Prusinska, M., \& Wiszniewski, G. (2018). Influence of temperature and Artemia enriched with $x$ 3 PUFAs on the early ontogenesis of Atlantic sturgeon, Acipenser oxyrinchus Mitchill, 1815. Aquaculture Resources, 49, 1740-1751.

Kottelat, M., Whitten, A., Kartikasari, S.N.J., \& Wirjoatmodjo, S. (1993). Freshwater fishes of Western Indonesia and Sulawesi. Periplus Edition. Jakarta. 293 pp.

Kurniawan, K., Gustiano, R., Kusmini, I.I., \& Prakoso, V.A. (2021). Genetic resources preservation and utilization of Indonesian native freshwater fish consumption. Ecology, Environment and Conservation, 27(1), 227-233.

Laila, K. (2018). Effects of different temperatures on growth and survival of common carp (Cyprinus carpio). The National Conference on Multidiscipline Sciences. Universitas Asahan, North Sumatera, p. 275-281.

Nytrø, A.V. (2013). The effect of temperature and fish size on growth of juvenile lumpfish (Cyclopterus lumpus L.). Master Thesis. University of Tromsø, Kjørsvikbugen.

Orina, P.S., Rasowo, J., Oyoo-Okoth, E., Musa, S., \& Charo-Karisa, J.M.M.H. (2016). Combined effects of photoperiod and temperature on growth and survival of African catfish (Clarias gariepinus, Burchell 1822) larvae under laboratory conditions. Journal of Applied Aquaculture, 28(1), 17-25. https:/ /doi.org/10.1080/10454438.2015.1113763.

Prakoso, V.A. \& Kurniawan, K. (2020). Oxygen consumption of barred loach Nemacheilus fasciatus (Valenciennes, 1846) on different temperatures. IOP Conference Series: Earth and Environmental Science, $457 \mathrm{pp}$. 
Prakoso, V.A., Pouil, S., Prabowo, M.N.I., Sundari, S., Arifin, O.Z., Subagja, J., Affandi, R., Kristanto, A.H., \& Slembrouck, J. (2019). Effects of temperature on the zootechnical performances and physiology of giant gourami (Osphronemus goramy) larvae. Aquaculture, 510, 160-168.

Pratama, B.A., Susilowati, T., \& Yuniarti, T. (2018). The effects of different temperatures on hatching time, hatching rate, survival and the growth of giant gouramy bastar (Osphronemus goramy) larvae. Jurnal Sains Akuakultur Tropis, 2(1), 59-65.

Pinder, A.C., Britton, J.R., Harrison, A.J., Nautiyal, P., Bower, S.D., Cooke, S.J., Lockett, S., ....., \& Raghavan, R. (2019). Mahseer (Tor spp.) fishes of the world: Status, challenges and opportunities for conservation. Reviews in Fish Biology and Fisheries, 29(2), 417-452.

Pyanuth, R., Sommai, C., \& Naraid, S. (2020). Effects of temperature on growth performance and water quality in culture system of butter catfish (Ompok bimaculatus). Songklanakarin Journal of Sciience and Technology, 42(6), 1253-1258.

Takata, R., Silva, W.d.S.e., Costa, D.C., Melillo Filho, R., \& Luz, R.K. (2014). Effect of water temperature and prey concentrations on initial development of Lophiosilurus alexandri Steindachner, 1876 (Siluriformes: Pseudopimelodidae), a freshwater fish. Neotropical Ichthyology, 12, 853-859.

Qudus, R.R., Lili, W., \& Rosidah. (2012). The effects of different stocking density on survival and growth of mahseer (Tor soro) larvae. Jurnal Perikanan dan Kelautan, 3(4), 253-260.

Ridwantara, D., Buwono, I.D., \& Handaka, A.A. (2019). The survival and growth of the mantap common carp (Cyprinus carpio) in different temperatures. Jurnal Perikanan dan Kelautan, 10(1), 46-54.
Rønnestad, I., Yúfera, M., Ueberschär, B., Ribeiro, L., Saele, $\varnothing$., \& Boglione, C. (2013). Feeding behaviour and digestive physiology in larval fish: Current knowledge, and gaps and bottlenecks in research. Reviews in Aquaculture, 5, S59-S98.

Sarma, D., Haldar, R.S., Das, P., \& Mahanta, P.C. (2010). Management in seed production of golden mahseer, Tor putitora in hatchery conditions.. Aquaculture Asia, XV(4), 31-35.

Sihombing, T.Y. (2018). Effect of temperature differences on growth and survival of comet fish (Carassius auratus). Thesis. Universitas Sumatra Utara, Medan, $79 \mathrm{pp}$.

Subagja, J., Asih, S., \& Gustiano, R. (2006). Broodstock management for mahseer Tor soro breeding program. Media Akuakultur, 1(1), 7-11.

Subagja, J., Prakoso, V.A., Arifin, O.Z., Suparyanto, Y., \& Suhud, E.H. (2018). The growth of domesticated Asian redtail catfish (Hemibagrus nemurus) in different rearing altitudes. Media Akuakultur, 13(2), 59-65.

Singh, S.P., Sharma, J.G., Ahmad, T., \& Chakrabarti, R. (2013). Effect of water temperature on the physiological responses of asian catfish Clarias batrachus (Linnaeus 1758). Asian Fisheries Science, 26, 26-38.

Tang, U.M., Muchlisin, Z.A., Syawal, H., \& Masjudi, H. (2017). Effect of water temperature on the physiological stress and growth performance of tapah (Wallago leeri) during domestication. Archives of Polish Fisheries, 25(3), 165-171.

Wahyuningsih, H., Zairin, M.Jr., Sudrajat, A.O., Tumbelaka, L.I.T.A., \& Manalu, W. (2012). The changes of blood plasm and gonadal maturation of Tor soro broodstock female in pond culture. Jurnal Iktiologi Indonesia, 12(1), 25-34. 